\title{
Refinement of Technology for the Management of Collar Rot in Apple
}

\author{
Bhupesh Gupta $^{1 *}$, Usha Sharma ${ }^{2}$ and Shalini Verma ${ }^{1}$ \\ ${ }^{1}$ Department of Plant Pathology, Dr YS Parmar University of Horticulture and Forestry, \\ Nauni, Solan 173230 Himachal Pradesh, India \\ ${ }^{2}$ Regional Horticultural Research and Training Station, Mashobra, Shimla - 171007 \\ (HP), India \\ *Corresponding author
}

\begin{tabular}{|l|}
\hline Ke y w o r d s \\
$\begin{array}{l}\text { Collar rot, } \text { Phytophthora } \\
\text { cactorum, Trichoderma } \\
\text { viride, Integrated } \\
\text { management }\end{array}$ \\
\hline Article Info \\
\hline $\begin{array}{l}\text { Accepted: } \\
\text { 17 May } 2018 \\
\text { Available Online: } \\
\text { 10 June } 2018\end{array}$ \\
\hline
\end{tabular}

\section{Introduction}

In Himachal Pradesh apple is being cultivated over 1,11,896 ha with annual production of 4,68,134 MT (Anoymous, 2017). Though, cultivation of apple has revolutionized the socio-economic status of Himachal Pradesh farmers, yet the productivity of apple is 4.18 MT/ha (Anonymous, 2017) which is relatively very low in comparison to global productivity of 16.88 MT/ha (FAO, 2016). Different factors are responsible for low productivity of apple among these diseases play an important role. Apple crop falls prey to wide range of fungal, bacterial and viral pathogens, where collar rot of apple caused by Phytophthora cactorum is one of the most important soil borne diseases following white root rot of apple (Gupta et al., 2004). In India, collar rot was first reported from Himachal Pradesh in 
1960 (Anonymous, 1961) and is well established that collar rot disease of pome and stone fruit trees including apple was primarily caused by Phytophthora cactorum (Utkhede, 1986). The incidence of disease was up to 48 per cent in the orchards of Shimla and Kinnaur districts of Himachal Pradesh. Keeping in view the aforesaid information a survey was conducted in two districts and refinement of existing technology was carried out through on farm testing.

\section{Materials and Methods}

A survey was conducted in different locations of Kinnaur and Shimla districts to record incidence of collar rot and orchards were selected to conduct location specific trials in both the districts. The disease incidence was recorded by randomly selecting about 50 plants in an orchard and using the following formula

No. of plants showing collar rot symtoms Disease incidence $(\%)=$

Total number of plants observed

To manage the disease, factors viz. heavy soils, faulty basin preparation and Northern aspect that are representing the specific microclimatic conditions were considered. To create awareness among farmers about proper management practices as basin preparation viz. improving water drainage, avoidance of flood irrigation and orchard floor management; training programmes were organized in the surveyed areas of the districts. Method demonstrations on the basin management were given to the farmers to avoid moisture retention in collar region and improving moisture maintenance in feeding zone. Floor management by manual weeding in basin area of the tree from time to time (May-August) was also demonstrated, that helped in reducing the humidity in collar region and improving the aeration in the orchard.
Keeping in view the losses resulted due to the disease, on farm trials (OFTs) at five locations in Kinnaur district (two each in Kalpa and Nichar blocks, one in Pooh block), and Shimla district (Two in Chirgaon, one each at Rohru, Jubbal and Kotkhai) were conducted to assess and refine the existing technology for management of the disease by integrating agrochemicals with Trichoderma viride which included three drenchings in rainy season in two consecutive years with following treatments $\mathrm{T}_{1}$ [metalaxyl $(8 \%)+$ mancozeb (64\%)@0.5\%], $\mathrm{T}_{2}$ [mancozeb (75\%) @ $0.5 \%$ ], $\mathrm{T}_{3}$ [Trichoderma viride@0.5\%], $\mathrm{T}_{4}$ [one drenching with metalaxyl (8\%) + mancozeb (64\%) @0.5\% followed by two drenchings with Trichoderma viride @0.5\%], $\mathrm{T}_{5}$ [one drenching with mancozeb (75\%) @ $0.5 \%$ followed by two drenchings with Trichoderma viride @0.5\%] and $\mathrm{T}_{6}$ [Control/farmers' practice] during 2010-11 and 2011-12 in farmers' field.

Data obtained were subjected to analysis by following Gomez and Gomez (1984). Least significant difference (LSD) at 5 per cent level was calculated.

\section{Results and Discussion}

A perusal of the data presented in Table 1 revealed that the disease was prevalent in all surveyed blocks of both the districts. Disease incidence ranged between 0.0 to 48.0 per cent in two districts. Maximum disease incidence (48.0\%) was recorded at Rangori village of Rampur Bushehr block followed by Mauli (46.0\%) in Jubbal and Kotkhai of Shimla district. However, minimum disease incidence $(0.0 \%)$ was recorded in Peja (Chirgaon), Kandyali and Jar (Narkanda), and Rushkalang and Dubling (Pooh). Among blocks, the highest disease incidence was recorded in Jubbal and Kotkhai (31.20\%) followed by Rampur Bushehr (28.0\%) whereas the least incidence was recorded in Pooh (3.3\%). 
Table.1 Prevalence of collar rot of apple in Shimla and Kinnaur districts of Himachal Pradesh

\begin{tabular}{|c|c|c|c|c|c|}
\hline $\begin{array}{l}\text { S. } \\
\text { No. }\end{array}$ & Shimla District & $\begin{array}{l}\text { Disease } \\
\text { Incidence (\%) }\end{array}$ & $\begin{array}{l}\text { S. } \\
\text { No. }\end{array}$ & Kinnaur District & $\begin{array}{c}\text { Disease Incidence } \\
(\%)\end{array}$ \\
\hline & Jubbal and Kotkhai & & & Nichar & \\
\hline 1. & Mauli & 46.0 & 35. & Bari & 20.0 \\
\hline 2. & Graug & 20.0 & 36. & Sungra & 8.0 \\
\hline 3. & Kharapathar & 30.0 & 37. & Puje & 16.0 \\
\hline 4. & Shari & 32.0 & 38. & Katgaon & 10.0 \\
\hline \multirow[t]{3}{*}{5.} & Ruhil Dhar & 28.0 & 39. & Kafnu & 4.0 \\
\hline & Mean & 31.20 & & Mean & 11.6 \\
\hline & Chirgaon & & & Kalpa & \\
\hline 6. & Peja & 0.0 & 40. & Powari & 12.0 \\
\hline 7. & Sandhasu & 10.0 & 41. & Reckong Peo & 4.0 \\
\hline 8. & Devidhar & 8.0 & 42. & Telangi & 6.0 \\
\hline 9. & Masali & 6.0 & 43. & Pangi & 8.0 \\
\hline \multirow[t]{3}{*}{10.} & Jara & 4.0 & 44. & Roghi & 20.0 \\
\hline & Mean & 5.60 & & Mean & 10.0 \\
\hline & Rohru & & & Pooh & \\
\hline 11. & Kasaini & 20.0 & 45. & Skiba & 10.0 \\
\hline 12. & Barasali & 10.0 & 46. & Rispa & 4.0 \\
\hline 13. & Summer Kot & 2.0 & 47. & Rushkalang & 0.0 \\
\hline 14. & Bhaloon Kainchi & 10.0 & 48. & Pooh & 2.0 \\
\hline \multirow[t]{3}{*}{15.} & Anu Basa & 6.0 & 49. & Rarang & 4.0 \\
\hline & Mean & 9.6 & 50. & Dubling & 0.0 \\
\hline & Chopal & & & Mean & 3.3 \\
\hline 16. & Maraug & 20.0 & & Mean Kinnaur & 8.31 \\
\hline 17. & Gorli & 30.0 & & & \\
\hline 18. & Chopal & 24.0 & & & \\
\hline 19. & Nerva & 12.0 & & & \\
\hline \multirow[t]{3}{*}{20.} & Kedi & 6.0 & & & \\
\hline & Mean & 18.4 & & & \\
\hline & Theog & & & & \\
\hline 21. & Sandhu & 6.0 & & & \\
\hline 22. & Matyana & 16.0 & & & \\
\hline 23. & Guthan & 20.0 & & & \\
\hline \multirow[t]{3}{*}{24.} & Kaleend & 12.0 & & & \\
\hline & Mean & 13.5 & & & \\
\hline & Narkanda & & & & \\
\hline 25. & Kandyali & 0.0 & & & \\
\hline 26. & Ekantbari & 2.0 & & & \\
\hline 27. & Mohen & 4.0 & & & \\
\hline \multirow[t]{3}{*}{28.} & Jar & 0.0 & & & \\
\hline & Mean & 1.5 & & & \\
\hline & Nankhari & & & & \\
\hline 29. & Delath & 10.0 & & & \\
\hline 30. & Kandreri & 30.0 & & & \\
\hline \multirow[t]{3}{*}{31.} & Surad Bangla & 2.0 & & & \\
\hline & Mean & 14.0 & & & \\
\hline & Rampur Bushehr & & & & \\
\hline 32. & Gopalpur & 24.0 & & & \\
\hline 33. & Sarahan & 12.0 & & & \\
\hline \multirow[t]{3}{*}{34.} & Rangori & 48.0 & & & \\
\hline & Mean & 28.0 & & & \\
\hline & Mean Shimla & 13.27 & & & \\
\hline
\end{tabular}


Table.2 Individual and combined effects of agrochemicals with Trichoderma viride on the management of collar rot of apple in Kinnaur district

\begin{tabular}{|c|}
\hline Treatment \\
\hline $\mathrm{T}_{1}$ [metalaxyl $(8 \%)+$ mancozeb $\left.(64 \%) @ 0.5 \%\right]$ \\
\hline $\mathrm{T}_{2}$ [mancozeb (75\%) @ $\left.0.5 \%\right]$ \\
\hline $\mathrm{T}_{3}[$ Trichoderma viride @0.5\%] \\
\hline $\begin{array}{l}\mathrm{T}_{4} \text { [One drenching with metalaxyl }(8 \%)+\text { mancozeb }(64 \%) @ 0.5 \% \\
\text { followed by two drenchings with Trichoderma viride @ } 0.5 \%]\end{array}$ \\
\hline $\begin{array}{l}\mathrm{T}_{5} \text { [one drenching with mancozeb }(75 \%) @ 0.5 \% \text { followed by two } \\
\text { drenchings with Trichoderma viride @ } 0.5 \% \text { ] }\end{array}$ \\
\hline $\mathrm{T}_{6}$ [Control/farmers' practice] \\
\hline
\end{tabular}

Figures in parentheses are angular transformations

* Pooled data for five locations

\section{Percent healing of lesion*}

\begin{tabular}{|c|c|}
\hline Year I & Year II \\
\hline $36.26(37.01)$ & $58.69(49.99)$ \\
\hline $32.61(34.81)$ & $48.81(43.73)$ \\
\hline $28.44(32.21)$ & $46.23(42.82)$ \\
\hline $37.65(37.83)$ & $60.77(51.20)$ \\
\hline $31.20(33.95)$ & $52.69(46.53)$ \\
\hline $0.00(0.00)$ & $0.00(0.00)$ \\
\hline$(1.53)$ & $(2.09)$ \\
\hline
\end{tabular}

Table.3 Individual and combined effects of agrochemicals on management of collar rot of apple in Shimla district

\begin{tabular}{l} 
Treatment \\
\hline $\mathrm{T}_{1}$ [metalaxyl $(8 \%)+$ mancozeb $\left.(64 \%) @ 0.5 \%\right]$ \\
\hline $\mathrm{T}_{2}[$ mancozeb $(75 \%) @ 0.5 \%]$ \\
\hline $\mathrm{T}_{3}[$ Trichoderma viride@0.5\%] \\
\hline $\mathrm{T}_{4}[$ One drenching with metalaxyl (8\%)+ mancozeb (64\%)@0.5\% \\
followed by two drenchings with Trichoderma viride@0.5\%] \\
\hline $\mathrm{T}_{5}$ [one drenching with mancozeb (75\%)@ 0.5\% followed by two \\
drenchings with Trichoderma viride@0.5\%] \\
\hline $\mathrm{T}_{6}[$ Control/farmers' practice] \\
\hline $\mathrm{LSD}_{0.05}$
\end{tabular}

Figures in parentheses are angular transformations

* Pooled data for five locations

Comparison of two districts revealed that Shimla district had higher incidence $(13.27 \%)$ than Kinnaur district $(8.31 \%)$. High disease incidence in Shimla and low in Kinnaur was due to wet and dry temperate conditions prevailing during peak periods of incidence (July-September), respectively. Similar observations were recorded by Gupta et al., (2004).

The data obtained from on farm trials conducted in five locations of Kinnaur district was pooled and presented in the Table 2 . It is evident from the data (Table 2) that $\mathrm{T}_{4}$ [One drenching with metalaxyl $(8 \%)+$ mancozeb

\begin{tabular}{|c|c|}
\hline \multicolumn{2}{|c|}{ Percent healing of lesion** } \\
\hline Year I & Year II \\
\hline $33.20(35.14)$ & $53.00(46.71)$ \\
\hline $29.20(32.68)$ & $45.20(42.22)$ \\
\hline $28.60(32.28)$ & $45.80(42.57)$ \\
\hline $33.80(35.51)$ & $55.60(48.24)$ \\
\hline $29.60(32.86)$ & $47.20(43.38)$ \\
\hline 0.00 & 0.00 \\
$(2.27)$ & $(3.48)$
\end{tabular}

(64\%) @0.5\% followed by two drenching with Trichoderma viride @0.5\%] showed maximum per cent healing of the lesion $(60.77 \%)$ after second year of progress which was statistically at par $(58.69 \%)$ with $\mathrm{T}_{1}$ [metalaxyl $(8 \%)+$ mancozeb (64\%) @0.5\%] while minimum per cent healing $(28.44 \%$ in $1^{\text {st }}$ year and $46.23 \%$ in second year) was observed in $\mathrm{T}_{3}$.

The data obtained from the on farm trials conducted in Shimla district are pooled and presented in Table 3. Perusal of the data (Table 3) revealed that $\mathrm{T}_{4}$ [One drenching with metalaxyl (8\%) + mancozeb (64\%) 
@ $0.5 \%$ followed by two drenching with Trichoderma viride@0.5\%] has shown maximum percent healing of the lesion (55.60 $\%$ ) after second year of progress, this was statistically at par with $(53.00 \%)$ by $\mathrm{T}_{1}$ [metalaxyl (8\%) + mancozeb (64\%) @0.5\%]. While minimum per cent healing $(28.60 \%$ in first year $45.80 \%$ in second year) was observed in $\mathrm{T}_{3}$ and $\mathrm{T}_{2}(29.20 \%$ in first year and $45.20 \%$ in second year) which were statistically at par with each other.

Earlier studies indicated that biological control agents are effective in the management of soil borne diseases (Chet, 1987; Bhardwaj and Kumar, 2002) for their ability of mycoparasitism, mycolysis, direct and indirect toxic effects (Ajitha and Lakshmidevi, 2010). Studies have indicated that the fungi not only act as biocontrol agents, but also stimulate plant resistance, plant growth and development resulting in an increase in crop production (Laila Naher 2014; Bastakoti et al., 2017). The biocontrol activity involving mycoparasitism, antibiotics and competition for nutrients, also induces defense responses or systemic resistance responses in plants. These responses are an important part of Trichoderma in biocontrol program. Currently, Trichoderma spp., is being used to control plant diseases in sustainable diseases management systems. The integration of biocontrol agents with agro-chemicals enhances sustainability of the treatment and thus the healing of the plants. Total control of collar rot was obtained under pot culture conditions when application was done 7 days prior to inoculation with pathogen (Sharma et al., 2014).

\section{References}

Ajitha P.S. and Lakshmidevi, N. 2010. Effect of volatile and non-volatile compounds from Trichoderma spp. against Colletotrichum capsici incitant of anthracnose on Bell peppers. Nature and Sci. 8: 265-296.

Anonymous, 1961. Notes of research and investigations. Orchardist N.Z. 34: 68.

Anonymous, 2017. http://hphorticulture.nic.in

Bastakoti, S. Belbase, S. Manandhar, S. and Arjyal, C. 2017. Trichoderma species as biocontrol agent against soil borne fungal pathogens. Nepal Journal of Biotechnology. 5(1): 39-45.

Bhardwaj, L.N. and Kumar, B. 2002. Management of collar rot of apple with biocontrol agents and fungicides. Journal of Mycology and Plant Pathology (India), (abstr).

Chet, I. 1987. Trichoderma -application, mode of action, and potential as biocontrol agent of soilborne plant pathogenic fungi. In: Innovative approaches to plant disease control (Ed.) I. Chet, John Wiley and Sons, New York, pp. 147-160.

FAO, 2016. http://www.fao.org/faostat/

Gupta, B., Bhardwaj, L.N., Handa, A. and Sharma, U. 2004. Status of collar rot in temperate fruits of Himachal Pradesh. Journal of Current Science 5: 257-260.

Laila, N., Umi, K.Y., Ahmad, I. and Kausar, H. 2014. Trichoderma spp.: A biocontrol agent for sustainable management of plant diseases. Pakistan Journal of Botany 46: 1489-1493.

Sharma, I.M., Negi, H.S. and Sharma, S. 2014. Integrated management of collar rot of apple caused by Phytophthora cactorum. Indian Phytopathology 67: 168-173.

Utkhede, R.S. 1986. In vitro screening of world germplasm collection for resistance to Phytophthora cactorum crown rot. Scientia Horticulture 29: 205-210. 


\section{How to cite this article:}

Bhupesh Gupta, Usha Sharma and Shalini Verma. 2018. Refinement of Technology for the Management of Collar Rot in Apple. Int.J.Curr.Microbiol.App.Sci. 7(06): 1551-1556.

doi: https://doi.org/10.20546/ijcmas.2018.706.185 